\title{
Pengaruh Kualitas Kehidupan Kerja, Disiplin Kerja dan Kompetensi terhadap Kinerja Pegawai pada PD. BPR BKK Kebumen
}

\section{Oleh: \\ Parmin}

\begin{abstract}
Abstrak
Penelitian ini bertujuan untuk menguji dan menganalisis pengaruh kualitas kehidupan kerja, kompetensi dan disiplin kerja terhadap kinerja pegawai baik secara parsial maupun secara simultan pada pegawai PD BPR BKK Kebumen. Hipotesis yang diuji adalah terdapat pengaruh antara (1), Kualitas kehidupan kerja terhadap kinerja pegawai pada PD BPR BKK Kebumen. (2) Kompetensi terhadap kinerja pegawai pada PD BPR BKK Kebumen. (3) Disiplin kerja terhadap kinerja pegawai pada PD BPR BKK Kebumen. (4) Kualitas kehidupan kerja, Kompetensi dan Disiplin kerja secara bersama-sama terhadap kinerja pegawai pada PD BPR BKK Kebumen. Populasi dalam penelitian ini adalah pegawai di PD BPR BKK Kebumen yang berjumlah 251 orang. Sampel penelitian diambil dengan menggunakan rumus Slovin yaitu 72 responden. Metodologi dalam penelitian ini adalah menggunakan metode survey dengan teknik regresi linier berganda. Pengumpulan data dilakukan dengan menggunakan kuesioner dengan memakai skala likert.

Hasil dari penelitian ini menunjukkan bahwa hipotesis yang dikemukakan dalam penelitian ini yaitu hasil uji persamaan regresi memperlihatkan kinerja pegawai $=32,575+0,126 \mathrm{X} 1+0,329 \mathrm{X} 2+0,319 \mathrm{X} 3$ sehingga nilai kinerja pegawai terdapat hubungan dengan kualitas kehidupan kerja, kompetensi dan disiplin kerja adalah 32,575 yang tergolong berkinerja baik, variabel kualitas kehidupan kerja, kompetensi dan disiplin kerja secara bersama-sama mempunyai pengaruh positif yang signifikan terhadap kinerja pegawai PD BPR BKK Kebumen, hal ini dibuktikan dengan nilai $\mathrm{R}=0,666$ pada tingkat keyakinan $95 \%$. Hasil uji korelasi variabel kualitas kehidupan kerja dengan kinerja pegawai adalah sebesar $\mathrm{r}$ hitung $=0,504$, hasil uji korelasi variabel kompetensi dengan kinerja pegawai adalah sebesar $r$ hitung $=0,619$, sedangkan, hasil uji korelasi variabel disiplin kerja dengan kinerja pegawai adalah sebesar $r$ hitung $=0,610$ yang memiliki tingkat signifikansi 0,000 pada alpha 0,05 pada tingkat keyakinan $95 \%$. Nilai $r$ tabel ini dengan jumlah $n$ sebanyak 72 adalah 0,195. Sehingga jika dibandingkan $\mathrm{r}$ tabel $0,195<\mathrm{r}$ hitung $0,504,0,619$ dan 0,610 hal ini berarti variabel kuualitas kehidupan kerja, kompetensi dan disiplin kerja pegawai memiliki hubungan yang signifikan.

Berdasarkan hasil penelitian tersebut, memberikan implikasi penelitian bahwa kualitas kehidupan kerja, kompetensi dan disiplin kerja mampu mempengaruhi kinerja pegawai PD BPR BKK Kebumen secara bersama-sama. Peneliti menyarankan kepada pimpinan PD BPR BKK Kebumen untuk memperhatikan faktor yang berkaitan kehidupan kerja pegawai, konsisten dalam menerapkan aturan-aturan yang berlaku untuk membentuk perilaku dalam disiplin kerja pegawainya. Untuk para pegawai diharapkan untuk selalu meningkatkan kemampuan kompetensinya, karena dengan kompetensi yang baik dapat meningkatkan kinerjanya.
\end{abstract}


Kata Kunci: Kualitas Kehidupan Kerja, Kompetensi, Disiplin Kerja dan Kinerja Pegawai

\section{PENDAHULUAN}

\section{Latar Belakang Masalah}

Era globalisasi, masalah sumber daya manusia menjadi sorotan maupun tumpuan bagi perusahaan untuk tetap dapat bertahan di lingkungan bisnisnya. Sumber daya manusia merupakan peran utama dalam setiap kegiatan perusahaan. Walaupun banyaknya sarana dan prasarana serta sumber daya, tanpa dukungan sumber daya manusia kegiatan perusahaan tidak akan berjalan dengan baik. Dengan demikian sumber daya manusia merupakan kunci pokok yang harus diperhatikan dalam segala kebutuhannya. Sumber daya manusia akan menentukan keberhasilan pelaksanaan kegiatan perusahaan. Untuk itu setiap organisasi perusahaan untuk senantiasa meningkatkan kualitas demi meningkatkan efektivitas dan efisiensi dalam pencapaian tujuan organisasi.

Sumber daya manusia memegang peranan penting bagi dinamisasi sebuah organisasi untuk mencapai tujuannya. Peranan sumber daya manusia diartikan sebagai bentuk kemampuan secara maksimal dalam menjalankan tugas yang diberikan organisasi sesuai dengan tugas pokok dan fungsinya yang mencakup seluruh aktivitas yang ada dalam organisasi tersebut mulai dari perencanaan, pengorganisasian, pelaksanaan kegiatan sampai pada evaluasi hasil kegiatan.

Kinerja merupakan salah satu ukuran dari perilaku yang aktual di tempat kerja yang bersifat multidimensional, dimana indikator kinerja meliputi kualitas kerja, kuantitas kerja, waktu kerja dan kerja sama dengan rekan kerja (Mathis dan Jackson, 2002).
Peningkatan kinerja karyawan akan membawa kemajuan bagi perusahaan untuk dapat bertahan dalam suatu persaingan lingkungan bisnis yang tidak stabil. Oleh karena itu upaya-upaya untuk meningkatkan kinerja karyawan merupakan tantangan manajemen yang paling serius karena keberhasilan untuk mencapai tujuan dan kelangsungan hidup perusahaan tergantung pada kualitas kinerja sumber daya manusia yang ada didalamnya.

Kinerja karyawan yang tinggi sangatlah diharapkan oleh perusahaan PD BPR BKK Kebumen. Semakin banyak karyawan yang mempunyai kinerja tinggi, maka produktivitas perusahaan secara keseluruhan akan meningkat sehingga perusahaan akan dapat bertahan dalam menghadapi persaingan industri perbankan. Karyawan dituntut untuk mampu menyelesaikan tugas dan tanggung jawabnya secara efektif dan efisien.

Berdasarkan hasil observasi yang dilakukan oleh peneliti mengindikasikan bahwa PD BPR BKK Kebumen masih mengalami permasalahan dengan kinerja pegawainya yang belum maksimal, hal ini tercermin masih ada kinerja pegawainya yang kinerjanya masih dibawah target yang telah ditetapkan.

$$
\text { Peran divisi SDM dapat }
$$
ditunjukkan dengan menciptakan kualitas kehidupan kerja yang dikenal dengan istilah Quality of Work Life (QWL) yang mendorong karyawan memaksimalkan kontribusinya pada pencapaian sasaran organisasi. QWL dapat dibangun dengan berbagai praktik pengelolaan yang memberikan kesempatan pengembangan karier secara adil bagi setiap individu yang bekerja. Sebuah organisasi akan 
bekerja dengan baik saat karyawan sebagai motor penggeraknya mampu untuk berkontribusi secara optimal. Suasana hubungan kemanusiaan yang serasi baik secara vertikal maupun horisontal antar karyawan akan mampu menciptakan lingkungan, suasana dan kondisi kerja yang nyaman. Proses penciptaan good human relationship dapat dilakukan manajemen perusahaan dengan menerapkan QWL karena tujuan pokok QWL adalah mengembangkan lingkungan kerja yang lebih baik bagi karyawan. Lingkungan kerja yang baik dapat berhubungan dengan keterikatan karyawan sebagai bentuk kepuasan atas pekerjaan yang telah dilakukan.

Kualitas kehidupan kerja merupakan suatu konsep atau filsafat manajemen dalam rangka perbaikan kualitas sumber daya manusia. Kualitas kehidupan kerja diartikan sebagai tehnik manajemen yang mencakup gugus kendali mutu, perkayaan pekerjaan, suatu pendekatan untuk bernegosiasi dengan serikat pekerja, upaya manajemen untuk memelihara kebugaran mental para karyawan, hubungan industrial yang serasi, manajemen yang partisipatif dan salah satu bentuk intervensi dalam pengembangan organisasional (French et al.,1990 dalam Arifin, 1999).

Fokus usaha QWL bukan hanya pada bagaimana orang dapat dapat melakukan pekerjaan dengan lebih baik melainkan bagaimana pekerjaan dapat menyebabkan pekerja menjadi lebih baik. Aspek khusus utama QWL adalah keterlibatan atau partisipasi dalam proses pembuatan keputusan organisasional yang mempengaruhinya. QWL secara operasional dapat menggambarkan aktivitas yang dapat dirasakan oleh pekerja sebagai usahausaha yang mengarah pada terciptanya kualitas kehidupan kerja yang lebih baik untuk mencapai peningkatan kinerja karyawan yang unggul, sehingga pihak manajemen perlu terlebih dahulu mengetahui apa yang menimbulkan dorongan dan kebutuhan karyawan dalam bekerja. Oleh karena itu, keberhasilan manajer ditentukan oleh seberapa jauh bawahan menjalankan tugas yang telah diberikan kepadanya dengan baik.

Untuk mendukung terhadap pencapaian kinerja karyawan maka seorang karyawan harus memiliki kompetensi. Hasil penelitian menunjukkan variabel kompetensi skill teknis, kompetensi skill non teknis, knowledge dan ability mempunyai pengaruh yang signifikan terhadap peningkatan kinerja karyawan. Penelitian selanjutnya dilakukan oleh Kartikawangi (2002) dalam sebuah jurnal dengan judul Karakteristik SDM yang Dibutuhkan Dunia Industri/Organisasi. Hasil dari penelitian ini menunjukkan karakteristik dasar yang dibutuhkan oleh perusahaan mencakup karakteristik umum (demografi) dan karakteristik khusus yang mencakup Knowledge, Skill, Ability dan Others.

Berdasarkan uraian di atas dapat disimpulkan bahwa kompetensi adalah kemampuan dan kemauan untuk melakukan sebuah tugas dengan kinerja yang efektif. Kesimpulan ini sesuai dengan yang dikatakan Michael Armstrong (1998), bahwa kompetensi adalah knowledge, skill dan kualitas individu untuk mencapai kesuksesan pekerjaannya. Kompetensi yang dimiliki oleh para pegawai PD. BPR. BKK Kebumen dirasa masih perlu ditingkatkan terutama untuk para karyawan yang dirasa tidak cukup untuk memenuhi tuntutan perkembangan bisnisnya. Masalah yang lain berkaitan dengan kompetensi karyawan PD. BPR. BKK Kebumen 
yaitu karyawan yang usia sudah mulai tua seringkali kompetensi yang dimiliki sudah tidak relevan lagi dengan tuntutan pekerjaan sehingga karyawan tersebut akan cukup kesulitan untuk memberikan kinerja terbaikknya.

Disiplin kerja dari para karyawan juga sangat diperlukan dalam mencapai tujuan pengembangan perusahaan. Disiplin kerja yang diharapkan perusahaan PD BPR BKK Kebumen adalah kesetiaan dan ketaatan seluruh karyawan kepada aturan-aturan, normanorma yang berlaku atas perusahaan PD BPR BKK Kebumen.

Dalam setiap perusahaan yang diinginkan adalah jenis disiplin yang timbul dari diri sendiri atas dasar kerelaan dan kesadaran. Akan tetapi dalam kenyataan selalu menyatakan bahwa disiplin itu lebih banyak disebabkan adanya paksaan dari luar. Untuk itu perlu melaksanakan kegiatan pendisiplinan yang mencakup disiplin preventif dan disiplin korektif.

Disiplin preventif merupakan kegiatan yang dilakukan dengan maksud untuk mendorong para karyawan PD BPR BKK Kebumen agar secara sadar mentaati berbagai standar dan aturan sehingga dapat dicegah berbagai penyelewengan/pelanggaran. Disiplin korektif merupakan kegiatan yang diambil untuk menangani pelanggaran yang telah terjadi terhadap aturanaturan dan mencoba untuk menghindari pelanggaran lebih lanjut, kegiatan korektif ini dapat berupa suatu hukuman / tindakan pendisiplinan (Dicipline Action) yang wujudnya berupa skorsing kepada karyawan yang melanggar peraturan.

Terkait dengan norma disiplin, salah satunya adalah norma yang terkait dengan ketentuan waktu dalam melaksanakan tugas dan tanggung jawab pekerjaannya. Kapan karyawan harus mulai masuk kerja, dan keluar, berapa lama melaksanakan tugas, baik yang melaksanakan tugas administrasi di dalam kantor, maupun yang menjalankan tugas di lapangan, dan sebagainya, yang kesemuanya itu wajib ditaati sebagai salah satu ciri dari karyawan yang memiliki sifat disiplin.

Permasalahan waktu jam kerja merupakan masalah yang paling sering terjadi. Karyawan sering datang ke kantor tidak tepat waktu sampai sekarang masih terjadi di PD BPR BKK Kebumen. Ketika ditelusuri penyebabnya, ternyata terdapat berbagai alasan. Alasan yang dapat diterima adalah karyawan harus mendatangi atau bertemu dengan nasabah yang lokasinya berada antara rumah karyawan dan kantor terlebih dahulu sehingga berakibat datang terlambat masuk kantor. Meskipun demikian, ke depan praktek-praktek seperti ini harus ditertibkan dengan mematuhi dan menjalankan peraturan yang berlaku. Oleh karena itu, disiplin harus ditumbuh kembangkan agar tumbuh pula ketertiban dan kinerja karyawan. Tanpa adanya disiplin yang baik, sulit untuk mewujudkan rencana perusahaan untuk dapat lebih berkembang dan dapat bersaing dalam industri perbankan, khususnya di kabupaten Kebumen.

\section{Perumusan Masalah}

Berdasarkan pembatasan masalah tersebut di atas, maka perumusan masalah yang merupakan landasan penelitian ini dapat dirumuskan sebagai berikut:

1. Apakah terdapat pengaruh positif antara kualitas kehidupan kerja terhadap kinerja pegawai pada PD. BPR BKK Kebumen.

2. Apakah terdapat pengaruh positif antara kompetensi 
terhadap kinerja pegawai pada PD. BPR BKK Kebumen.

3. Apakah terdapat pengaruh positif antara disiplin kerja terhadap kinerja pegawai pada PD. BPR BKK Kebumen.

4. Apakah terdapat pengaruh positif antara kualitas kehidupan kerja, kompetensi dan disiplin kerja pegawai secara bersama-sama pada PD. BPR BKK Kebumen.

\section{KERANGKA TEORITIS DAN PENGEMBANGAN HIPOTESIS}

Kinerja karyawan sering diartikan sebagai pencapaian tugas selama periode tertentu oleh seseorang atau kelompok orang dalam suatu organisasi, sesuai dengan wewenang dan tanggung jawabnya masingmasing, dalam rangka mencapai visi, misi, dan tujuan organisasi. Menurut Irawan (2000:588) menyatakan bahwa "Kinerja (performance) adalah hasil kerja yang konkrit, dapat diamati, dan dapat diukur". Sehingga kinerja merupakan hasil kerja yang dicapai oleh pegawai dalam pelaksanaan tugas yang berdasarkan ukuran dan waktu yang telah ditentukan.

Menurut Richard I. Handerson (1984) dalam Wirawan (2009: 53) dimensi kinerja adalah kualitas-kualitas atau wajah suatu pekerjaan atau aktivitas-aktivas yang terjadi di tempat kerja yang konduktif terhadap pengukuran". Dimensi kinerja menyediakan alat untuk melukiskan keseluruhan cakupan aktivitas di tempat kerja. Sementara itu, tanggung jawab dan kewajiban menyediakan suatu deskripsi depersonalisasi. Menurut Wirawan (2009:54) dimensi kinerja dikelompokkan menjadi tiga jenis yaitu hasil kerja, perilaku kerja, dan sifat pribadi yang berhubungan dengan pekerjaan
Sementara Gomez (2001:142) mengemukakan unsur yang berkaitan dengan kinerja terdiri dari :

a. Quantity of work, yakni jumlah pekerjaan yang dapat diselesaikan pada periode tertentu.

b. Quality of work, yaitu kualitas pekerjaan yang dicapai berdasarkan syarat yang ditentukan.

c. Job knowledge, yakni pemahaman pegawai pada prosedur kerjadan informasi teknis tentang pekerjaan.

d. Creativeness, yaitu kemampuan menyesuaikan diri dengan kondisi dan dapat diandalkan dalam pekerjaan.

e. Cooperation, yaitu kerjasama dengan rekan kerja dan atasan.

f. Dependability, yakni kemampuan menyelesaikan pekerjaan tanpa tergantung kepada orang lain.

g. Inisiative, yakni kemampuan melahirkan ide-ide dalam pekerjaan.

h. Personal qualities, yaitu kemampuan dalam berbagai bidang pekerjaan.

\section{Kualitas Kehidupan Kerja (Quality of Work Life )}

Menurut Davis, et.al (1994), QWL mengacu kepada keadaan menyenangkan atau tidak menyenangkan lingkungan pekerjaan bagi karyawan. Tujuan utama penerapan QWL adalah pengembangan lingkungan kerja yang sangat baik bagi karyawan dan juga produksi. Fokus utama QWL adalah lingkungan kerja dan semua pekerjaan di dalammya harus sesuai dengan orang-orang dan teknologi. Filippo (2005) mendefinisikan QWL sebagai setiap pekerjaan (perbaikan) yang terjadi pada setiap tingkatan dalam suatu organisasi untuk meningkatkan efektivitas organisasi yang lebih besar 
melalui peningkatan martabat dan pertumbuhan manusia.

Menurut Cascio (2006), QWL dapat diartikan menjadi dua pandangan yaitu: pandangan pertama menyebutkan bahwa QWL merupakan sekumpulan keadaan dan praktek dari tujuan organisasi (contohnya: pemerkayaan pekerjaan, kebijakan promosi dari dalam, kepenyeliaan yang demokratis, partisipasi karyawan dan kondisi kerja yang nyaman). Pandangan kedua menyatakan bahwa QWL merupakan persepsi-persepsi karyawan seperti karyawan merasa aman, secara relative merasa puas serta mendapatkan kesempatan tumbuh dan berkembang sebagai layaknya manusia.

QWL menghasilkan lingkungan kerja yang lebih manusiawi. Penerapan QWL bertujuan untuk berusaha memenuhi kebutuhan tingkat tinggi karyawan dan kebutuhan pokok karyawan. Mengelola dengan menyediakan sarana dan prasarana yang berusaha mewujudkan lingkungan kerja dan iklim kerja yang kondusif yang dapat mendorong karyawan selalu berinovasi dan berkreasi, serta struktur yang fleksibel dengan pembagian tugas dan wewenang dan tanggung jawab yang jelas dan manusiawi, memperhatikan kemampuan karyawan dan usahanya dalam mencapai kariernya. Pengelolaan manajemen sumber daya manusia dengan menerapkan QWL ditujukan untuk mewujudkan kehidupan kerja yang berkualitas sehingga pada akhirnya mencapai kinerja yang unggul, produktivitas yang tinggi dan mencapai kepuasan diri dan lingkungan kerja.

Pada prakteknya belum banyak perusahaan yang menerapkan QWL sebagai salah satu misinya. Pihak manajemen masih lebih memperhatikan kepentingan dalam pencapaian tujuan perusahaan ketimbang kepentingan karyawan.

Menurut Cascio (2006), terdapat sembilan indikator dalam penerapan Quality of Work Life, yaitu:

1. Partisipasi karyawan

$$
\text { Partisipasi }
$$

adalah

keterlibatan metal dan emosional orang-orang dalam situasi kelompok yang mendorong mereka untuk memberikan konstribusi kepada tujuan kelompok dan berbagai tanggung jawab pencapaian tujuan itu (Davis, et.al, 1994). Menurut Cascio (2006) partisipasi karyawan dapat diimplementasikan melalui: (1) kerjasama dengan karyawan, (2) partisipasi karyawan dalam rapat dan (3) peningkatan kualitas tim.

Menurut Davis, et.al (1994), bahwa keberhasilan partisipasi langsung berkaitan dengan seberapa baiknya terpenuhinya 7 (tujuh) prasyarat, yaitu: (1) waktu yang cukup untuk berpartisipasi, (2) maslahatnya lebih besar dari kerugian, (3) relevan dan kepentingan pegawai, kemampuan pegawai memadai untuk menangani bidang garapan partisipasi, (5) kemampuan berkomunikasi timbal balik, (6) tidak timbul perasaan teracam bagi kedua belah pihak, dan (7) masih dalam bidang keleluasaan pekerjaan.

2. Penyelesaian konflik

Konflik merupakan suatu gejala ketika individu atau kelompok menunjukkan sikap atau perilaku "bermusuhan" terhadap individu atau kelompok lain, sehingga mempengaruhi kinerja dari salah satu atau semua pihak yang terlibat (Suhendi, et.al. 2010). 
Menurut Robbins (2003) bahwa konflik merupakan suatu proses yang bermula ketika satu pihak merasakan bahwa pihak lain telah mempengaruhi secara negatif, sesuatu yang menjadi keperdulian pihak pertama.

Tingkat konflik yang berlebihan dapat merintangi efektivitas organisasi/perusahaan, yang dapat mengakibatkan berkurangnya kepuasan kerja karyawan, meningkatnya keabsenan dan pengunduran diri karyawan. Hal tersebut dapat menyebabkan menurunnya produktivitas. Penyelesaian terhadap konflik-konflik yang terjadi di lingkungan kerja sangat diperlukan. Menurut Cascio (2006), beberapa hal yang dapat dilakukan oleh anggota organisasi/perusahaan dalam menyelesaikan konflik adalah (1) keterbukaan, (2) proses penyampaian keluaran secara formal, dan (3) pertukaran pendapat.

3. Komunikasi

Setiap manajer dan
karyawan perlu memiliki
kemampuan membangun
komunikasi yang efektif sebaga
dasar esensial di dalam
memimpin dan mengelola
organisasi/perusahaan.
Kemampuan berkomunikasi
karyawan merupakan salah satu
bentuk mutu sumber daya
manusia (Mangkuprawira, et.al.
2007).

Menurut Davis, et.al (1994), organisasi tidak mungkin terjadi apabila tidak terdapat proses komunikasi. Apabila tidak ada komunikasi, para pegawai tidak dapat mengetahui apa yang dilakukan rekan sekerjanya, pimpinan tidak dapat menerima masukan informasi, dan para penyelia tidak dapat memberikan instruksi. Koordinasi kerja tidak mungkin dilakukan dan organisasi akan runtuh karena tidak terbentuknya komunikasi. Maka setiap tindakan komunikasi mempengaruhi organisasi dengan cara tertentu. Sebagai akibat dari perbedaan pekerjaan dan peringkat karyawan dalam perbedaan peran akan mempengaruhi pola komunikasi antara mereka (pimpinan dan karyawan).

Komunikasi yang baik
karyawan dan karyawan dengan karyawan dapat menciptakan motivasi kerja bagi karyawan, yang pada akhirnya akan meningkatkan kepuasan dan kinerja dari karyawan. Menurut Cascio (2006) komunikasi di dalam organisasi/perusahaan dapat dilaksanakan melalui 3 (tiga) kegiatan, yaitu: (1) pertemuan tatap muka, (2) pertemuan kelompok dan publikasi.

4. Kesehatan kerja Dalam Pasal 86 ayat (1) huruf (a) Undang-Undang Nomor 13 Tahun 2003 tentang kesehatan kerja merupakan salah satu hak pekerja atau buruh untuk itu pengusaha wajib melaksanakan secara sistematis dan terintergrasi dengan sistem manajemen perusahaan. Upaya kesehatan kerja bertujuan untuk melindungi pekerja atau buruh guna mewujudkan produktivitas kerja yang optimal, dengan cara pencegahan kecelakaan dan penyakit akibat kerja, pengendalian bahaya ditempat 
kerja, promosi kesehatan, pengobatan, dan rehabilitasi (Santoso, 2004).

Sebagai akibat dari proses bekerja, tenaga kerja atau karyawan dapat mengalami stress. Stres yang berlebihan dapat menyebabkan sakit, gangguan pada fisik dan mental dari karyawan yang menyebabkan karyawan tidak dapat bekerja secara optimal.

Menurut Soewondo (1992)

dalam Suhendi, et.al (2010) menyatakan bahwa penyebab stres kerja terdiri atas empat hal utama, yaitu: (1) kondisi dan situasi pekerjaan, (2) pekerjaannya, (3) job requirement seperti status pekerjaan dan karir yang tidak jelas, dan (4) hubungan interpersonal. Oleh karena itu, untuk menghindari dampak stres akibat pekerjaan, perusahaan harus memperhatikan kesehatan karyawan dengan cara menyediakan beberapa fasilitas, yaitu: (a) pusat kesehatan, (b) pusat kesehatan gigi, (c) program pusat senam kebugaran, (d) program rekreasi dan, (e) program konseling.

5. Keselamatan kerja

Dengan majunya industrialisasi, mekanisme, dan modernisasi, maka dalam kebanyakan hak berlangsung pulalah peningkatan intesitas kerja operasional dan tempat kerja para pekerja. Hal ini memerlukan pengerahan tenaga kerja secara intensif pula dari para pekerja. Kelelahan, kurang perhatian akan hal-hal ini, kehilangan keseimbangan dan lain-lain merupakan akibat dari padanya dan menyebabkan terjadinya kecelakaan. Oleh karena itu perlu adanya jaminan keselamatan bagi karyawan dalam menjalankan pekerjaannya (Santoso, 2004).

Perusahaan harus dapat menjamin keselamatan karyawannya. Menurut Cascio (2006), keselamatan kerja yang dilaksanakan oleh perusahaan yaitu: (1) komite keselamatan, (2) tim penolong gawat darurat dan, (3) program keselamatan kerja (seperti asuransi kecelakaan).

6. Keamanan kerja

Keamanan bekerja sangat penting bagi karyawan. Perlunya kesepakatan mengenai pekerjaan antara karyawan dengan perusahaan. Kesepakatan tersebut berkenaan dengan gaji, kontrak kerja dan sebagainya. Hal ini ditujukan agar tidak ada pemecatan secara sepihak yang dapat dilakukan oleh pihak perusahaan.

Cascio

mengelompokkan rasa aman karyawan terhadap perusahaan adalah: (1) jaminan tidak ada pemberhentian karyawan tetap dan (2) program pensin bagi karyawan yang telah mengabdi kepada perusahaan.

7. Kompensasi yang layak

Kompensasi meliputi bentuk pembayaran tunai langsung, pembayaran tidak langsung dalam bentuk manfaat karyawan, dan insentif untuk memotivasi karyawan agar bekerja keras untuk mencapai produktivitas yang semakin tinggi. Kompensasi merupakan sebuah komponen penting dalam hubungannya dengan karyawan (Mangkuprawira, 2009). 
Pemberian kompensasi
dapat meningkatkan prestasi kerja dan memotivasi karyawan. Oleh karena itu, perhatian perusahaan terhadap pengaturan kompensasi secara rasional dan adil sangat diperlukan. Bila karyawan memandang pemberian kompensasi tidak memadai, prestasi kerja, motivasi maupun kepuasan kerja cenderung menurun.

8. Kebanggaan

Karyawan yang punya rasa bangga dan memiliki akan bekerja optimal untuk kemajuan perusahaan. Menumbuhkan rasa bangga dan memiliki atas perusahaan di mana kita bekerja sangat mengaruhi kinerja dan totalitas seseorang terhadap perusahaannya. Walaupun caranya berbeda-beda, esensinya adalah satu: meningkatkan rasa bangga karyawan yang mampu menyulut produktivitas perusahaan ke titik optimal.

Dari masa bekerja, praktisi SDM berharap karyawan akan lebih lama berkarya, lebih loyal. Namun, komitmen bukan berarti aman-aman saja. Kebanggaan selayaknya membuat karyawan selalu ingin meningkatkan diri dan memberi kontribusi yang besar ke perusahaan.

Menurut Cascio (2006), kebanggaan karyawan terhadap perusahaannya dipengaruhi oleh tiga hal yaitu: (1) identitas perusahaan, (2) partisipasi perusahaan dalam bidang kemasyarakatan dan, (3) keperdulian perusahaan terhadap lingkungan.

9. Pengembangan Karir

Pengembangan karir adalah suatu yang menunjukkan adanya peningkatan-peningkatan status seseorang dalam suatu organisasi dalam jalur karir yang telah ditetapkan dalam organisasi yang bersangkutan (Robbins, 2003). Pengembangan karir merupakan pendekatan formal yang dilakukan organisasi untuk menjamin orang-orang dalam organisasi mempunyai kualifikasi dan kemampuan serta pengalaman yang cocok ketika dibutuhkan.

\section{Kompetensi}

Kompetensi adalah karakteristik dasar dari seseorang yang memungkinkan mereka menghasilkan kinerja superior dalam pekerjaannya (Boulter, Dalziel dan Hill, 1996) dalam Wardah (2007). Makna kompetensi mengandung bagian kepribadian yang mendalam dan melekat pada seseorang dengan perilaku yang dapat diprediksi pada berbagai keadaan dan tugas pekerjaan. Prediksi siapa yang berkinerja baik dan kurang baik dapat diukur dari kriteria atau standar yang digunakan. Analisis kompetensi disusun sebagian besar untuk pengembangan karier, tetapi penentuan tingkat kompetensi dibutuhkan untuk mengetahui efektivitas tingkat kinerja yang diharapkan.

Menurut Boulter (1996) level kompetensi adalah sebagai berikut: Skill, Knowledge, Self concept, Self Image, Trait dan Motive. Skill atau keterampilan adalah kemampuan untuk melaksanakan suatu tugas dengan baik. Knowledge adalah informasi yang dimiliki seseorang untuk bidang khusus. Social role adalah sikap dan nilai-nilai yang dimiliki seseorang dan ditonjolkan dalam masyarakat (ekspresi nilai-nilai diri). Self image adalah pandangan orang terhadap diri sendiri, merekflesikan identitas. 
Kompetensi skill dan knowledge cenderung lebih nyata (visible) dan relative berada di permukaan (ujung) sebagai karakteristik yang dimiliki manusia. Kompetensi pengetahuan dan keahlian relatif mudah untuk dikembangkan, misalnya dengan program pelatihan untuk meningkatkan tingkat kemampuan sumber daya manusia. Sedangkan motif kompetensi dan trait berada pada kepribadian sesorang, sehingga cukup sulit dinilai dan dikembangkan. Salah satu cara yang paling efektif adalah memilih karakteristik tersebut dalam proses seleksi.

Ruky (2003) mengutip pendapat Spencer \& Spencer dari kelompok konsultan Hay \& Mac Ber bahwa kompetensi adalah "an underlying characteristic of an individual that is casually related to criterion referenced effective and/or superior performance in a job or situation" (karakteristik dasar seseorang yang mempengaruhi cara berpikir dan bertindak, membuat generalisasi terhadap segala situasi yang dihadapi, serta bertahan cukup lama dalam diri manusia).

The Jakarta Consulting Group (Susanto, 2002) memberikan batasan bahwa kompetensi adalah segala bentuk perwujudan, ekspresi, dan representasi dari motif, pengetahuan, sikap, perilaku utama agar mampu melaksanakan pekerjaan dengan sangat baik atau yang membedakan antara kinerja rata-rata dengan kinerja superior. Pendekatan ini dilihat dari sudut pandang individual.

Konsep kompetensi harus ada "Kriteria Pembanding" (Criterion Reference) untuk membuktikan bahwa elemen kompetensi mempengaruhi baik atau buruknya kinerja seseorang. Kompetensi adalah karateristik dasar seseorang yang ada hubungan sebab- akibat dengan prestasi kerja yang luar biasa atau dengan efektivitas kerja dan Dave Ulrich mengemukakan bahwa kompetensi adalah pengetahuan, keterampilan atau kemampuan individu yang diperagakan (Hutapea, 2008).

Menurut Boyatzis, Kompetensi adalah kapasitas yang ada pada seseorang yang bisa membuat orang tersebut mampu memenuhi apa yang disyaratkan oleh pekerjaan dalam suatu organisasi sehingga organisasi tersebut mampu mencapai hasil yang diharapkan sedangkan Woodruffe, membedakan Competence dan Competency, Competence diartikan sebagai konsep yang berhubungan dengan pekerjaan, yaitu menunjukkan wilayah kerja dimana orang dapat menjadi kompeten atau unggul sedangkan Competency merupakan konsep dasar yang berhubungan dengan orang, yaitu menunjukkan dimensi perilaku yang melandasi prestasi unggul.

Secara umum kompetensi lebih menekankan pada perilaku produktif yang harus dimiliki serta diperagakan oleh seseorang dalam melaksanakan suatu pekerjaan agar dapat berprestasi dalam pekerjaannya (Hutapea, 2008).

Faktor-faktor yang mendukung standar kompetensi adalah:

a. Pengetahuan dan keterampilan untuk mengerjakan suatu tugas dalam kondisi normal di tempat kerja.

b. Kemampuan mentransfer dan menerapkan kemampuan dan pengetahuan pada situasi dan lingkungan yang berbeda.

c. Standar kompetensi tidak berarti bila hanya terdiri dari kemampuan menyelesaikan tugas/pekerjaan saja, tetapi dilandasi pula dengan bagaimana dan mengapa tugas itu dikerjakan. 
Dengan demikian standar kompetensi merupakan rumusan tentang kemampuan yang dimiliki seseorang untuk melakukan suatu pekerjaan/tugas yang didasari atas pengetahuan, keterampilan, yang didukung sikap kerja dan penerapannya sesuai unjuk kerja yang dipersyaratkan.

Berdasarkan definisi kompetensi di atas, komponen-komponen atau karakteristik yang membentuk sebuah kompetensi menurut Spencer \& Spencer (1993) adalah:

1. Motives, yaitu konsistensi berpikir mengenai sesuatu yang diinginkan atau dikehendaki oleh seseorang, sehingga menyebabkan suatu kejadian. Motif tingkah laku seperti mengendalikan, mengarahkan, membimbing, memilih untuk menghadapi kejadian atau tujuan tertentu.

2. Traits, yaitu karakteristik fisik dan tanggapan yang konsisten terhadap informasi atau situasi tertentu.

3. Self Concept, yaitu sikap, nilai, atau imaginasi seseorang.

4. Knowledge, informasi seseorang dalam lingkup tertentu. Komponen kompetensi ini sangat kompleks. Nilai dari knowledge test, sering gagal untuk memprediksi kinerja karena terjadi kegagalan dalam mengukur pengetahuan dan kemampuan sesungguhnya yang diperlakukan dalam pekerjaan.

5. Skills, yaitu kemampuan untuk mengerjakan tugas-tugas fisik atau mental tertentu.

Komponen kompetensi motives dan traits disebut hidden competency karena sulit untuk dikembangkan dan sulit mengukurnya. Komponen kompetensi knowledge dan skills disebut visible competency yang cenderung terlihat, mudah dikembangkan dan mudah mengukurnya. Sedangkan komponen kompetensi self concept berada di antara kedua kriteria kompetensi tersebut.

\section{Disiplin Kerja}

Disiplin kerja merupakan sikap yang sangat diperlukan dan mendapat perhatian dalam setiap pekerjaan yang dilakukan oleh setiap orang dalam usaha untuk meningkatkan kinerja guna mencapai tujuan organisasi.

1. Singodimejo dalam Sutrisno (2009:85) mengatakan bahwa disiplin adalah sikap kesediaan dan kerelaan seseorang untuk mematuhi dan mentaati normanorma peraturan yang berlaku di sekitarnya.

2. Sinungan (2003;135) mendefinisikan disiplin sebagai: sikap kejiwaan dari seseorang atau sekelompok orang yang senantiasa berkehendak untuk mengikuti/mematuhi segala aturan/keputusan yang telah ditetapkan.

3. Fathoni (2006:172) mengartikan disiplin kerja sebagai: kesadaran dan kesediaan seseorang mentaati semua peraturan organisasi dan norma-norma sosial yang berlaku. Selanjutnya Fathoni menjelaskan bahwa: "Kedisiplinan diartikan bilamana karyawan selalu datang dan pulang tepat pada waktunya, mengerjakan semua pekerjaannya dengan baik, mematuhi semua peraturan perusahaan dan normanorma sosial yang berlaku."

4. Keith Davis (2003:129) menyatakan disiplin kerja sebagai pelaksanaan manajemen untuk memperteguh pedoman-pedoman dipandang erat keterkaitannya dengan kinerja. Pernyataan 
tersebut didukung oleh pendapat Malthis dan Jackson bahwa disiplin kerja berkaitan erat dengan perilaku karyawan dan berpengaruh terhadap kinerja.

5. Rivai, (2004) menyatakan disiplin kerja adalah suatu alat yang digunakan para manajer untuk berkomunikasi dengan karyawan agar mereka bersedia untuk mengubah suatu perilaku serta sebagai suatu upaya untuk meningkatkan kesadaran dan kesediaan seseorang menaati semua peraturan perusahaan dan norma-norma sosial yang berlaku.

6. Hasibuan (2004) berpendapat bahwa kedisiplinan adalah kesadaran dan kesediaan seseorang menaati semua peraturan perusahaan dan norma-norma sosial yang berlaku.

\section{Aspek-Aspek Disiplin Kerja}

Aspek-aspek yang terdapat dalam disiplin kerja berdasarkan dari definisi disiplin kerja menurut Siswanto dan Prijodarminto (dalam Hapsari, 198) dan Nitisemito (1982) antara lain:

1. Aspek pemahaman terhadap peraturan yang berlaku

Sebelum mematuhi suatu peraturan perlu diketahui apakah karyawan sudah mengetahui atau memahami standar atau peraturan dengan jelas. Seorang karyawan menunjukkan kedisiplinan yang baik bila perilakunya menunjukkan usaha-usaha untuk memahami secara jelas suatu peraturan, berarti karyawan secara proaktif berusaha mendapatkan informasi tentang peraturan sehingga karyawan akan rajin mengikuti briefing, membaca pengumuman atau menanyakan ketidakjelasan suatu peraturan.

2. Aspek kepatuhan dan ketaatan terhadap aturan standar
Karyawan mempunyai disiplin tinggi jika tidak memiliki catatan pelanggaran selama kerjanya, mentaati suatu peraturan tanpa ada paksaan dan secara sukarela dapat menyesuaikan diri dengan aturan organisasi yang telah ditetapkan. Senantiasa menghargai waktu sehingga membuat bekerja tepat waktu, tahu kapan memulai dan mengakhiri suatu pekerjaan, tahu membedakan kapan waktu istirahat dan kapan waktu bekerja serius, menyelesaikan suatu pekerjaan yang telah ditetapkan merupakan contoh dari bentuk-bentuk kepatuhan terhadap aturan standar.

3. Aspek pemberian hukuman jika terjadi pelanggaran

Disiplin sering dikonotasikan sebagai hukuman namun tidak semua ketentuan disiplin berbentuk hukuman. Hukuman hanya diberikan ketika seseorang karyawan melakukan pelanggaran. Pemberian hukuman juga dilakukan sesuai jenis dan tingkat pelanggaran yang dilakukan. Menurut Nitisemito bahwa aspek disiplin kerja karyawan diantaranya:

a. Bahwa umumnya disiplin yang sejati terdapat apabila para karyawan datang ke kantor dengan teratur dan tepat pada waktunya.

b. Berpakaian seragam di tempat kerja

c. Menggunakan bahan dan perlengkapan dengan hati-hati

d. Menghasilkan kuantitas dan kualitas pekerjaan yang memuaskan

e. Mengikuti cara bekerja yang ditentukan oleh 
kantor atau perusahaan dan menyelesaikan pekerjaan dengan semangat yang baik.

Sementara itu organisasi dalam rangka untuk mengetahui tingkat kedisiplinan kerja yang baik yaitu :

a. Kepatuhan tenaga kerja pada jam-jam kerja

b. Kepatuhan tenaga kerja terhadap perintah atasan serta tata tertib yang berlaku

c. Penggunaan dan pemeliharaan bahan-bahan dan alat kantor dengan hatihati

d. Bekerja dengan mengikuti cara-cara kerja yang telah ditetapkan telah organisasi atau perusahaan

Berdasarkan dari beberapa hal di atas, penulis menentukan aspek-aspek dalam disiplin kerja sebagai berikut:

1. Disiplin terhadap peraturanperaturan

Disiplin terhadap peraturanperaturan dapat diartikan sebagai ketaatan karyawan terhadap ketentuan-ketentuan yang berlaku di lingkungan kerjanya, hal ini meliputi peraturan yang tertulis maupun yang tidak tertulis. Disiplin ini dapat berupa ketaatan untuk memberitahukan bila tidak masuk kerja, berpakaian sesuai dengan ketentuan, ketaatan dalam menggunakan alat-alat perlengkapan yang ada.

2. Disiplin Waktu

Disiplin waktu dapat diberi pengertian sebagai ketaatan karyawan terhadap waktu kerja. Hal ini meliputi ketaatan karyawan terhadap jam masuk kerja, jam pulang kerja dan kehadiran di tempat kerja.

3. Disiplin terhadap tugas dan tanggung jawab

Disiplin terhadap tugas dan tanggung jawab ini dapat diberi pengertian sebagai ketaatan karyawan dalam melaksanakan tugas dan tanggung jawab yang dibebankan kepadanya. Hal ini meliputi ketaatan karyawan untuk mematuhi cara-cara kerja yang telah ditentukan, menerima tugas yang dibebankan dan ketaatan untuk menyelesaikan setiap tugas.

4. Menerima sanksi-sanksi apabila melanggar peraturan dan juga apabila melanggar tugas dan wewenang yang diberikan Hal ini diberi pengertian bahwa karyawan yang melanggar peraturanperaturan yang telah ditetapkan organisasi ataupun tidak menyelesaikan tugas dan tanggung jawab yang diembannya akan diberikan sanksi sesuai dengan peraturan yang berlaku.

Dari beberapa teori di atas dapat disimpulkan bahwa disiplin kerja merupakan suatu sikap, tingkah laku, dan perbuatan yang sesuai dengan peraturan baik tertulis maupun tidak tertulis, dan bila melanggar akan ada sanksi atas pelanggarannya, dengan indikator-indikator sebagai berikut: disiplin terhadap tugas dan tanggungjawab, disiplin terhadap waktu, disiplin terhadap aturan, 
senang dalam bekerja dan siap menerima sanki

\section{Kerangka Pemikiran}

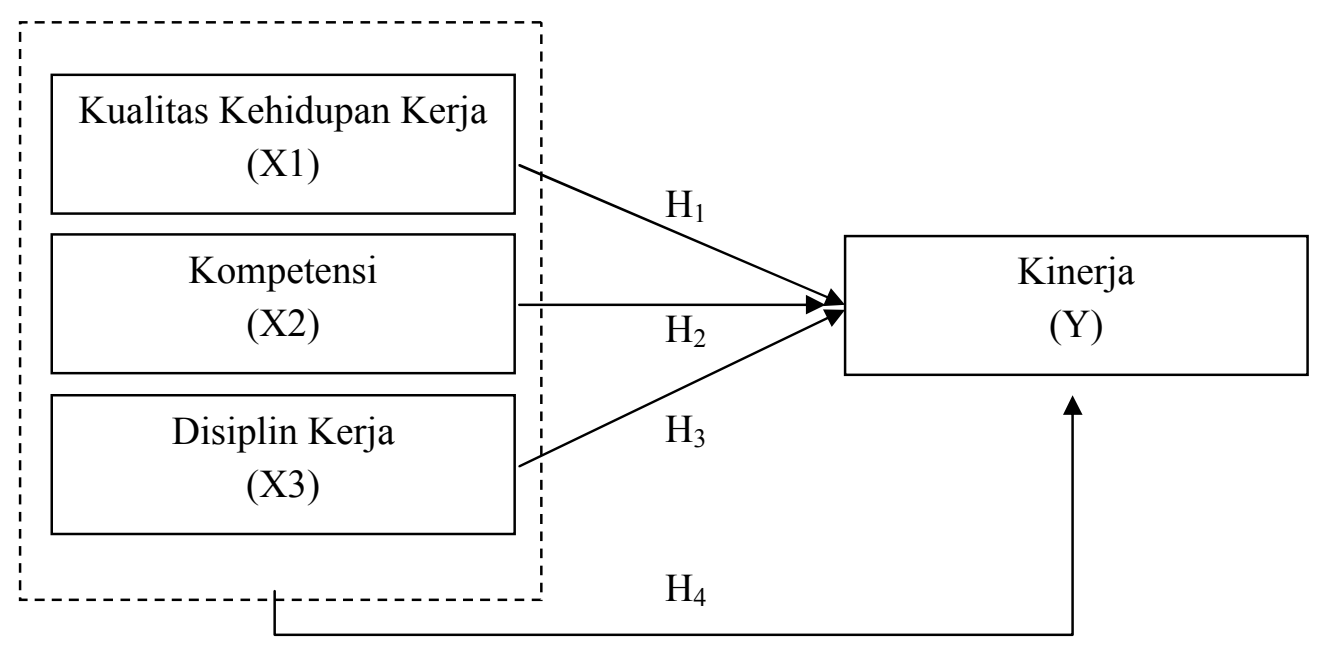

\section{Hipotesis Penelitian}

Berdasarkan kerangka konseptual di atas, maka diperoleh hipotesis yang akan diuji dalam penelitian ini adalah sebagai berikut:

$\mathrm{H}_{1} \quad$ : Terdapat pengaruh antara kualitas kehidupan kerja terhadap kinerja pegawai pada PD. BPR BKK Kebumen

$\mathrm{H}_{2}$ : Terdapat pengaruh antara kompetensi terhadap kinerja pegawai pada PD. BPR Kebumen

$\mathrm{H}_{3}$ : Terdapat pengaruh antara disiplin kerja terhadap kinerja pegawai pada PD. BPR Kebumen

$\mathrm{H}_{4}$ : Terdapat pengaruh antara kualitas kehidupan kerja, kompetensi dan disiplin kerja secara bersama-sama terhadap kinerja PD. BPR Kebumen

\section{Populasi dan Pengambilan Sampel}

Dalam penelitian ini, populasi sasaran adalah pegawai pada PD. BPR BKK Kebumen yang berjumlah 251 pegawai. Sampel yang digunakan dalam penelitian ini adalah bagian dari keseluruhan populasi yang ada yaitu pegawai pada PD. BPR BKK Kebumen. Menurut Umar (2000:78) perhitungan jumlah sampel dari populasi yang terdistribusi normal dapat dilakukan dengan rumus Slovin:

$$
\begin{aligned}
& ?=\frac{?}{\left(1+? ?^{?}\right)} \\
& \begin{array}{l}
\text { Dimana: } \\
\mathrm{n} \quad=\text { Jumlah sampel } \\
\mathrm{N} \quad=\text { Populasi } \\
\mathrm{e} \quad=\text { Persen kesalahan yang diinginkan atau ditolerir }(10 \%) \\
?=\frac{251}{\left(1+251.0,1^{?}\right)} \\
=72
\end{array}
\end{aligned}
$$


Berdasarkan rumus di atas maka dapat diketahui jumlah sampel yang digunakan dalam penelitian ini yaitu sebanyak 72 orang.

\section{Teknik Pengambilan Sampel}

Pengambilan sampel dalam suatu penelitian harus dapat mewakili populasinya. Dalam penentuan sampel dikenal dua teknik yaitu penentuan sampel secara acak (random sampling) yang mempunyai kemungkinan tinggi menetapkan sampel yang representative dan teknik pengambilan sampel secar tidak acak (non random sampling) yang lebih rendah kemungkinannya untuk menghasilkan sampel yang representative. Oleh karena itu, dalam penelitian ini yang dilakukan menggunakan teknik sample random sampling. Dalam sample random samping, pengambilan angota sampel dari populasi dilakukan secara acak tanpa memperhatikan strata yang ada dalam populasi tersebut (Sugiyono, 2008:82).

\section{Instrumen Penelitian}

Instrumen penelitian adalah suatu alat yang digunakan untuk mengukur fenomena-fenomena alam maupun social yang diamati oleh peneliti, secara spesifik fenomena disebut variabel. Dalam penelitian ini menggunakan instrument penelitian yang berbentuk kuesioner.

\section{Pengujian Hipotesis}

Pengujian hipotesis penelitian dimaksudkan untuk mengetahui apakah hipotesis nol yang diajukan $\left(\mathrm{H}_{0}\right)$ ditolak atau diterima pada taraf signifikan tertentu. Uji hipotesis yang akan dilakukan adalah berupa analisis regresi untuk mengetahui bentuk hubungan antar variabel. Analisis regresi yang dilakukan adalah analisis regresi sederhana berupa penyusunan persamaan regresi disertai uji keberartian (signifikansi) dan analisis regresi berganda berupa persamaan regresi disertai uji keberartian (signifikansi).

\section{Pengaruh Kualitas Kehidupan Kerja terhadap Kinerja Pegawai Pada PD BPR BKK Kebumen}

Perhitungan analisis regresi dalam penelitian ini menggunakan program SPSS. Hipotesis yang disusun dalam penelitian ini adalah sebagai berikut;

Ho 1 : Tidak ada pengaruh antara kualitas kehidupan kerja terhadap kinerja pegawai

Ha 1 : Ada pengaruh antara kualitas kehidupan kerja terhadap kinerja pegawai

\section{Tabel 1}

Koefisien Regresi Variabel Kualitas Kehidupan Kerja terhadap Kinerja Pegawai Coefficients $^{\mathrm{a}}$

\begin{tabular}{|c|c|c|c|c|c|c|c|}
\hline \multirow[t]{2}{*}{ Model } & \multicolumn{2}{|c|}{$\begin{array}{l}\text { Unstandardized } \\
\text { Coefficients }\end{array}$} & \multirow{2}{*}{$\begin{array}{c}\begin{array}{c}\text { Standardized } \\
\text { Coefficients }\end{array} \\
\text { Beta } \\
\end{array}$} & \multirow[b]{2}{*}{$\mathrm{t}$} & \multirow[b]{2}{*}{ Sig. } & \multicolumn{2}{|c|}{$\begin{array}{l}\text { Collinearity } \\
\text { Statistics }\end{array}$} \\
\hline & $\mathrm{B}$ & Std. Error & & & & Tolerance & VIF \\
\hline 1 (Constant) & 64,365 & 10,482 & & 6,141 &, 000 & & \\
\hline QWL & ,461 & ,095 &, 5 & 4,877 & ,000 & 1,000 & 1,000 \\
\hline
\end{tabular}

a. Dependent Variable: Kinerja

Sumber : Data primer, 2014

Dalam persamaan regresi pengaruh antara kualitas kehidupan kerja terhadap kinerja pegawai PD BPR BKK Kebumen adalah: 
Kinerja Pegawai $=64,365+0,461 \mathrm{X} 1$

Nilai Signifikan $(0,000) \quad(0,000)$

Hal ini berarti bahwa:

Koefisien regresi sebesar 64,365 artinya bahwa jika kualitas kehidupan kerja pada pegawai PD BPR BKK Kebumen dianggap tidak ada atau rendah maka kinerja pegawai PD BPR BKK Kebumen adalah 64,365 yang digolongkan memiliki nilai baik.

Nilai koefisien X1 (kualitas kehidupan kerja) sebesar 0,461 menunjukkan bahwa jika ada penambahan variabel kualitas kehidupan kerja sebesar 1 point, sedangkan variabel lainnya dianggap tetap, maka akan menaikkan kinerja PD BPR BKK Kebumen sebesar 0,461

Pada tabel di atas dijelaskan pula bahwa kualitas kehidupan kerja terhadap kinerja pegawai PD BPR BKK Kebumen diperoleh nilai signifikan 0,000; nilai t sebesar 4,877 dan nilai $\beta$ (beta) sebesar 0,095. Dengan ketentuan jika signifikan masih dibawah $\mathrm{p}<0,05$ dan besarnya t hitung $(4,887)>\mathrm{t}$ tabel $(0,195)$, maka dapat diindikasikan bahwa $\mathrm{H}_{0} 1$ ditolak dan Hal diterima. Dengan demikian dapat diartikan bahwa terdapat pengaruh positif dan signifikan antara kualitas kehidupan kerja terhadap kinerja pegawai PD BPR BKK Kebumen.

Kemudian berdasarkan hasil analisis data kualitas kehidupan kerja, kompetensi dan disiplin kerja terhadap kinerja pegawai PD BPR BKK Kebumen dengan menggunakan Software SPSS versi 18.0, diperoleh hasil mengenai hubungan kualitas kehidupan kerja PD BPR BKK Kebumen seperti pada tabel berikut ini:

Tabel. 2

Hasil Koefisien Korelasi Kualitas Kehidupan Kerja dengan Kinerja Pegawai Correlations

\begin{tabular}{|c|c|c|c|c|c|}
\hline & & QWL & Kompetensi & Disiplin_Kerja & Kinerja \\
\hline \multirow[t]{2}{*}{ QWL } & Pearson Correlation & 1 & $\begin{array}{r}603 \\
000\end{array}$ & ,598 & $\begin{array}{r}, 504 \\
000\end{array}$ \\
\hline & $\mathrm{N}$ & 72 & $\begin{array}{r}, 000 \\
72\end{array}$ & $\begin{array}{r}, 000 \\
72\end{array}$ & 72 \\
\hline \multirow[t]{3}{*}{ Kompetensi } & Pearson Correlation &, $603^{n}$ & 1 &, $748^{\prime \prime}$ & ,619" \\
\hline & Sig. (2-tailed) &, 000 & &, 000 &, 000 \\
\hline & $\mathrm{N}$ & 72 & 72 & 72 & 72 \\
\hline \multirow[t]{3}{*}{ Disiplin_Kerja } & Pearson Correlation &, 598 & ,748' & 1 & ,610" \\
\hline & Sig. (2-tailed) & ,000 & ,000 & &, 000 \\
\hline & $\mathrm{N}$ & 72 & 72 & 72 & 72 \\
\hline \multirow[t]{3}{*}{ Kinerja } & Pearson Correlation &, 504 & 619 & 610 & 1 \\
\hline & Sig. (2-tailed) &, 000 &, 000 &, 000 & \\
\hline & $\mathrm{N}$ & 72 & 72 & 72 & 72 \\
\hline
\end{tabular}

Sumber : Data Primer, 2014

Berdasarkan tabel di atas tersebut diketahui bahwa hubungan kualitas kehidupan kerja dengan kinerja pegawai pada PD BPR BKK Kebumen adalah sebesar $r$ hitung $=0,504$ yang memiliki tingkat signifikansi 0,000 pada alpha 0,05 pada tingkat keyakinan $95 \%$. Nilai $r$ tabel untuk jumlah $n$ sebanyak 72 adalah (n2) adalah 0,195. Sehingga jika dibandingkan $r$ tabel $0,195<r$ hitung 0,504 , hal ini 
berarti hipotesis diterima sehingga disimpulkan bahwa variabel kualitas kehidupan kerja dengan kinerja pegawai PD BPR BKK Kebumen secara parsial memiki hubungan yang signifikan.

\section{Tabel 3}

Model Summary Kualitas Kehidupan Kerja Model Summary

\begin{tabular}{|c|c|r|r|r|}
\hline Model & $\mathrm{R}$ & $\mathrm{R}$ Square & Adjusted R Square & Std. Error of the Estimate \\
\hline-1 &, $504^{\mathrm{a}}$ &, 254 &, 243 & 6,518 \\
\hline
\end{tabular}

a. Predictors: (Constant), QWL

Sumber : Data primer, 2014

Sedangkan berdasarkan hasil $\mathrm{r}^{2}$ ( $r$ square) sebesar 0,254 yang berarti variabel kualitas kehidupan kerja mampu menjelaskan variasi naik turunnya kinerja pegawai PD BPR BKK Kebumen sebesar 25\% saja.

\section{Pengaruh Kompetensi terhadap Kinerja Pegawai Pada PD BPR BKK Kebumen}

Perhitungan analisis regresi mengenai kompetensi terhadap kinerja pegawai PD BPR BKK Kebumen. Hipotesis yang disusun dalam penelitian ini adalah sebagai berikut;

Ho 2 : Tidak ada pengaruh antara kompetensi terhadap kinerja pegawai

Ha 2 : Ada pengaruh antara kompetensi terhadap kinerja pegawai

Tabel 4

Koefisien Regresi Variabel Kompetensi terhadap Kinerja Pegawai Coefficients $^{\mathrm{a}}$

\begin{tabular}{|c|c|c|c|c|c|c|c|}
\hline \multirow[t]{2}{*}{ Model } & \multicolumn{2}{|c|}{$\begin{array}{l}\text { Unstandardized } \\
\text { Coefficients }\end{array}$} & \multirow{2}{*}{$\begin{array}{c}\begin{array}{c}\text { Standardized } \\
\text { Coefficients }\end{array} \\
\text { Beta }\end{array}$} & \multirow[b]{2}{*}{$\mathrm{t}$} & \multirow[b]{2}{*}{ Sig. } & \multicolumn{2}{|c|}{$\begin{array}{l}\text { Collinearity } \\
\text { Statistics }\end{array}$} \\
\hline & $\mathrm{B}$ & Std. Error & & & & Tolerance & VIF \\
\hline 1 (Constant) & 44,917 & 10,698 & & 4,199 & ,000 & & \\
\hline Kompetensi & ,636 & ,096 & ,619 & 6,598 & ,000 & 1,000 & 1,000 \\
\hline
\end{tabular}

a. Dependent Variable: Kinerja

Sumber : Data primer, 2014

Dalam persamaan regresi pengaruh antara kompetensi terhadap kinerja pegawai PD BPR BKK Kebumen adalah:

Kinerja Pegawai $=44,917+0,636$ X2

Nilai Signifikan $(0,000) \quad(0,000)$

Hal ini berarti bahwa:

Koefisien regresi sebesar 44,917 artinya bahwa jika kompetensi pada pegawai PD BPR BKK Kebumen dianggap tidak ada atau rendah maka kinerja pegawai PD BPR BKK Kebumen adalah 44,917 yang digolongkan memiliki nilai baik.

Nilai koefisien X2 (kompetensi) sebesar 0,636 menunjukkan bahwa jika ada penambahan variabel kompetensi sebesar 1 point, sedangkan variabel lainnya dianggap tetap, maka akan menaikkan kinerja PD BPR BKK Kebumen sebesar 0,619 .

Pada tabel di atas dijelaskan pula bahwa kompetensi terhadap kinerja pegawai PD BPR BKK Kebumen diperoleh nilai signifikan 0,000; nilai t sebesar 
4,199 dan nilai $\beta$ (beta) sebesar 0,619 . Dengan ketentuan jika signifikan masih dibawah $\mathrm{p}<0,05$ dan besarnya $\mathrm{t}$ hitung $(4,199)>\mathrm{t}$ tabel $(0,195)$, maka dapat diindikasikan bahwa $\mathrm{H}_{0} 2$ ditolak dan $\mathrm{Ha}_{2}$ diterima. Dengan demikian dapat diartikan bahwa terdapat pengaruh positif dan signifikan antara kompetensi terhadap kinerja pegawai PD BPR BKK Kebumen.

Kemudian berdasarkan hasil analisis data kualitas kehidupan kerja, kompetensi dan disiplin kerja terhadap kinerja pegawai PD BPR BKK Kebumen dengan menggunakan Software SPSS versi 18.0, diperoleh hasil mengenai hubungan kompetensi pada PD BPR BKK Kebumen seperti pada tabel berikut ini:

Tabel. 5

Hasil Koefisien Korelasi Kompetensi dengan Kinerja Pegawai Correlations

\begin{tabular}{|ll|r|r|r|r|}
\hline & & \multicolumn{1}{c|}{ QWL } & Kompetensi & Disiplin_Kerja & Kinerja \\
\hline QWL & Pearson Correlation & 1 &, 603 &, 598 &, 504 \\
& Sig. (2-tailed) & &, 000 &, 000 &, 000 \\
& $\mathrm{~N}$ & 72 & 72 & 72 & 72 \\
\hline Kompetensi & Pearson Correlation &, 603 & 1 &, 748 &, 619 \\
& Sig. (2-tailed) &, 000 &, 000 &, 000 \\
& $\mathrm{~N}$ & 72 & 72 & 72 & 72 \\
\hline Disiplin_Kerja & Pearson Correlation &, 598 &, 748 & 1 &, 610 \\
& Sig. (2-tailed) &, 000 &, 000 &, 000 \\
& $\mathrm{~N}$ & 72 & 72 & 72 & 72 \\
\hline Kinerja & Pearson Correlation &, 504 &, 619 &, 610 & 1 \\
& Sig. (2-tailed) &, 000 &, 000 &, 000 & 72 \\
& $\mathrm{~N}$ & 72 & 72 & 72 \\
\hline
\end{tabular}

${ }^{\star \star}$. Correlation is significant at the 0.01 level (2-tailed).

Sumber : Data Primer, 2014

Berdasarkan tabel di atas tersebut diketahui bahwa hubungan kompetensi dengan kinerja pegawai pada PD BPR BKK Kebumen adalah sebesar $\mathrm{r}$ hitung = 0,619 yang memiliki tingkat signifikansi 0,000 pada alpha 0,05 pada tingkat keyakinan 95\%. Nilai $r$ tabel untuk jumlah $n$ sebanyak 72 adalah (n-2) adalah 0,195 . Sehingga jika dibandingkan $r$ tabel $0,195<r$ hitung 0,619 , hal ini berarti hipotesis diterima sehingga disimpulkan bahwa variabel kompetensi dengan kinerja pegawai PD BPR BKK Kebumen secara parsial memiliki hubungan yang signifikan.

Tabel 6
$\begin{gathered}\text { Model Summary Kompetensi } \\
\text { Model Summary }\end{gathered}$
\begin{tabular}{|c|c|r|r|r|}
\hline Model & R & R Square & Adjusted R Square & Std. Error of the Estimate \\
\hline-1 &, $619^{2}$ &, 383 &, 375 & 5,924 \\
\hline a. Predictors: (Constant), Kompetensi & \\
Sumber : Data primer, 2014
\end{tabular}

Sedangkan berdasarkan hasil $\mathrm{r}^{2}$ ( $r$ square) sebesar 0,375 yang berarti variabel kompetensi mampu menjelaskan variasi naik turunnya kinerja pegawai PD BPR BKK Kebumen sebesar 37\% saja. 


\section{Pengaruh Disiplin Kerja terhadap Kinerja Pegawai Pada PD BPR BKK Kebumen}

Perhitungan analisis regresi mengenai disiplin kerja terhadap kinerja pegawai PD BPR BKK Kebumen. Hipotesis yang disusun dalam penelitian ini adalah sebagai berikut;

Ho 3 : Tidak ada pengaruh antara disiplin kerja terhadap kinerja pegawai

Ha 3 : Ada pengaruh antara disiplin kerja terhadap kinerja pegawai

Tabel 7

Koefisien regresi Variabel Disiplin Kerja terhadap Kinerja Pegawai Coefficients $^{\mathrm{a}}$

\begin{tabular}{|c|c|c|c|c|c|c|c|}
\hline \multirow[t]{2}{*}{ Model } & \multicolumn{2}{|c|}{$\begin{array}{l}\text { Unstandardized } \\
\text { Coefficients }\end{array}$} & \multirow{2}{*}{$\begin{array}{c}\begin{array}{c}\text { Standardized } \\
\text { Coefficients }\end{array} \\
\text { Beta }\end{array}$} & \multirow[b]{2}{*}{$\mathrm{t}$} & \multirow[b]{2}{*}{ Sig. } & \multicolumn{2}{|c|}{$\begin{array}{c}\text { Collinearity } \\
\text { Statistics }\end{array}$} \\
\hline & $\mathrm{B}$ & Std. Error & & & & Tolerance & VIF \\
\hline 1 (Constant) & 46,807 & 10,659 & & 4,391 &, 000 & & \\
\hline Disiplin_Kerja & ,676 & , 105 & ,610 & 6,444 &, 000 & 1,000 & 1,000 \\
\hline
\end{tabular}

a. Dependent Variable: Kinerja

Sumber : Data primer, 2014

Dalam persamaan regresi pengaruh antara disiplin kerja terhadap kinerja pegawai PD BPR BKK Kebumen adalah:

Kinerja Pegawai $=46,807+0,676$ X3

Nilai Signifikan $(0,000) \quad(0,000)$

Hal ini berarti bahwa:

Koefisien regresi sebesar 46,807 artinya bahwa jika disiplin kerja pada pegawai PD BPR BKK Kebumen dianggap tidak ada atau rendah maka kinerja pegawai PD BPR BKK Kebumen adalah 46,807 yang digolongkan memiliki nilai baik.

Nilai koefisien X3 (disiplin kerja) sebesar 0,610 menunjukkan bahwa jika ada penambahan variabel disiplin kerja sebesar 1 point, sedangkan variabel lainnya dianggap tetap, maka akan menaikkan kinerja PD BPR BKK Kebumen sebesar 0,610

Pada tabel di atas dijelaskan pula bahwa disiplin kerja terhadap kinerja pegawai PD BPR BKK Kebumen diperoleh nilai signifikan 0,000; nilai t sebesar 6,444 dan nilai $\beta$ (beta) sebesar 0,610 . Dengan ketentuan jika signifikan masih dibawah $\mathrm{p}<0,05$ dan besarnya $\mathrm{t}$ hitung $(6,444)>\mathrm{t}$ tabel $(0,195)$, maka dapat diindikasikan bahwa $\mathrm{H}_{0} 3$ ditolak dan $\mathrm{Ha}_{3}$ diterima. Dengan demikian dapat diartikan bahwa terdapat pengaruh positif dan signifikan antara disiplin kerja terhadap kinerja pegawai PD BPR BKK Kebumen.

Kemudian berdasarkan hasil analisis data kualitas kehidupan kerja, kompetensi dan disiplin kerja terhadap kinerja pegawai PD BPR BKK Kebumen dengan menggunakan Software SPSS versi 18.0, diperoleh hasil mengenai hubungan disiplin kerja pada PD BPR BKK Kebumen seperti pada tabel berikut ini: 
Tabel 8

Hasil Koefisien Korelasi Disiplin Kerja

dengan Kinerja Pegawai

Correlations

\begin{tabular}{|ll|r|r|r|r|}
\hline & & \multicolumn{1}{|c|}{ QWL } & Kompetensi & Disiplin_Kerja & \multicolumn{1}{c|}{ Kinerja } \\
\hline QWL & Pearson Correlation & 1 &, 603 &, 598 &, 504 \\
& Sig. (2-tailed) & &, 000 &, 000 &, 000 \\
& $\mathrm{~N}$ & 72 & 72 & 72 & 72 \\
\hline Kompetensi & Pearson Correlation &, 603 & 1 &, 748 &, 619 \\
& Sig. (2-tailed) &, 000 &, 000 &, 000 \\
& $\mathrm{~N}$ & 72 & 72 & 72 & 72 \\
\hline Disiplin_Kerja & Pearson Correlation &, 598 &, 748 & 1 &, 610 \\
& Sig. (2-tailed) &, 000 &, 000 &, 000 \\
& $\mathrm{~N}$ & 72 & 72 & 72 & 72 \\
\hline Kinerja & Pearson Correlation &, 504 &, 619 &, 610 & 1 \\
& Sig. (2-tailed) &, 000 &, 000 &, 000 & 72 \\
& $\mathrm{~N}$ & 72 & 72 & 72 \\
\hline
\end{tabular}

${ }^{* \star}$. Correlation is significant at the 0.01 level (2-tailed).

Sumber : Data Primer, 2014

Berdasarkan tabel 4.20 di atas tersebut diketahui bahwa hubungan kompetensi dengan kinerja pegawai pada PD BPR BKK Kebumen adalah sebesar $\mathrm{r}$ hitung $=0,610$ yang memiliki tingkat signifikansi 0,000 pada alpha 0,05 pada tingkat keyakinan 95\%. Nilai $r$ tabel untuk jumlah $n$ sebanyak 72 adalah (n-2) adalah 0,195 . Sehingga jika dibandingkan $r$ tabel $0,195<r$ hitung 0,610 , hal ini berarti hipotesis diterima sehingga disimpulkan bahwa variabel disiplin kerja dengan kinerja pegawai PD BPR BKK Kebumen secara parsial memiliki hubungan yang signifikan.

\section{Tabel 9}

Model Summary Kompetensi Model Summary

\begin{tabular}{|c|c|r|r|r|}
\hline Model & $\mathrm{R}$ & $\mathrm{R}$ Square & Adjusted R Square & Std. Error of the Estimate \\
\hline-1 &, $610^{\mathrm{a}}$ &, 372 &, 363 & 5,977 \\
\hline
\end{tabular}

a. Predictors: (Constant), Disiplin_Kerja

Sumber : Data primer, 2014

Sedangkan berdasarkan hasil $r^{2}$ ( $r$ square) sebesar 0,372 yang berarti variabel kompetensi mampu menjelaskan variasi naik turunnya kinerja pegawai PD BPR BKK Kebumen sebesar 37\% saja.

\section{Pengaruh Kualitas Kehidupan Kerja, Kompetensi dan Disiplin Kerja terhadap Kinerja Pegawai Pada PD BPR BKK Kebumen}

Berdasarkan hasil analisis data kualitas kehidupan kerja, kompetensi dan disiplin kerja terhadap kinerja pegawai PD BPR BKK Kebumen. Hipotesis yang disusun dalam penelitian ini adalah sebagai berikut;

Ho 4 : Tidak ada pengaruh antara kualitas kehidupan kerja, kompetensi dan disiplin kerja secara simultan terhadap kinerja pegawai

Ha 4 : Ada pengaruh antara kualitas kehidupan kerja, kompetensi 
dan disiplin kerja secara simultan terhadap kinerja pegawai

Tabel 10

Hasil Analisis Regresi Ganda Kualitas Kehidupan Kerja, Kompetensi, Disiplin Kerja terhadap Kinerja Pegawai Coefficients $^{\mathrm{a}}$

\begin{tabular}{|c|c|c|c|c|c|c|c|}
\hline \multirow[t]{2}{*}{ Model } & \multicolumn{2}{|c|}{$\begin{array}{l}\text { Unstandardized } \\
\text { Coefficients }\end{array}$} & \multirow{2}{*}{$\begin{array}{c}\begin{array}{c}\text { Standardized } \\
\text { Coefficients }\end{array} \\
\text { Beta }\end{array}$} & \multirow[b]{2}{*}{$\mathrm{t}$} & \multirow[b]{2}{*}{ Sig. } & \multicolumn{2}{|c|}{$\begin{array}{l}\text { Collinearity } \\
\text { Statistics }\end{array}$} \\
\hline & $B$ & Std. Error & & & & Tolerance & VIF \\
\hline 1 (Constant) & 32,575 & 11,305 & & 2,882 & ,005 & & \\
\hline QWL & 126 & 108 & (138 & 1,170 & 246 & ,587 & 1,703 \\
\hline Kompetensi & ,329 & 146 & , 321 & 2,250 & ,028 & 403 & 2,484 \\
\hline Disiplin_Kerja & ,319 & , 157 & 288 & 2,027 & ,047 & ,406 & 2,461 \\
\hline
\end{tabular}

a. Dependent Variable: Kinerja

Sumber: Data primer, 2014

Untuk melihat pengaruh kualitas kehidupan kerja, kompetensi dan disiplin kerja terhadap kinerja pegawai pada PD BPR BKK Kebumen, maka dilakukan uji beberapa hal berikut ini:

Persamaan Regresi

Kinerja Pegawai $=32,575+0,126$ X1 $+0,329$ X2 $+0,319$ X3

Nilai Sig. $\quad(0,005) \quad(0,264) \quad(0,028) \quad(0,047)$

Hal ini berarti bahwa:

Koefisien regresi sebesar 32,575 artinya bahwa jika kualitas kehidupan kerja, kompetensi dan disiplin kerja dianggap tidak ada atau rendah maka kinerja pegawai PD BPR BKK Kebumen memiliki nilai baik.

Nilai koefisien X1 (Kualitas Kehidupan Kerja) sebesar 0,126 menunjukkan bahwa jika ada penambahan variabel kualitas kehidupan kerja sebesar 1 point, sedangkan variabel lainnya dianggap tetap/constant, maka akan meningkatkan kinerja pegawai pada pegawai PD BPR BKK Kebumen sebesar 0,126 point.

Nilai koefisien X2 (Kompetensi) sebesar 0,329 menunjukkan bahwa jika ada penambahan variabel kompetensi sebesar 1 point, sedangkan variabel lainnya dianggap tetap/constant, maka akan meningkatkan kinerja pegawai pada pegawai PD BPR BKK Kebumen sebesar 0,329 point.

Nilai koefisien X3 (Disiplin Kerja) sebesar 0,319 menunjukkan bahwa jika ada penambahan variabel disiplin kerja sebesar 1 point, sedangkan variabel lainnya dianggap tetap/constant, maka akan meningkatkan kinerja pegawai pada pegawai PD BPR BKK Kebumen sebesar 0,319 point.

\section{Koefisien Korelasi}

Koefisien korelasi menjelaskan hubungan antara variabel kualitas kehidupan kerja, kompetensi dan disiplin kerja terhadap kinerja pegawai pada PD BPR BKK Kebumen. Nilai koefisien korelasi terletak antara -1 sampai dengan 1 $(-1 \leq \mathrm{r} \geq 1)$.

Berdasarkan hasil analisis melalui regresi berganda ditemukan adanya hubungan positif yang kuat dan signifikan variabel kualitas kehidupan kerja, kompetensi dan disiplin kerja terhadap kinerja pegawai pada PD BPR BKK Kebumen. Hal ini telihat dari nilai korelasi sebesar $r=0,666$. 
Koefisien Determinasi

Koefisien determinasi adalah koefisien yang berfungsi untuk menjelaskan kemampuan independen untuk menjelaskan variasi perubahan naik turunnya variabel dependen. Nilai $\mathrm{R}$ mempunyai interval antara 0 sampai $1(0 \leq \mathrm{R} \leq 1)$. Semakin besar $\mathrm{R}$ (mendekati 1), semakin baik hasil untuk model regresi tersebut dan semakin mendekati 0 , maka variabel independen secara tidak dapat menjeleskan variabel dependen.

Berdasarkan hasil analisis melalui regresi berganda ditemukan adanya hubungan positif yang kuat antara kualitas kehidupan kerja, kompetensi dan disiplin kerja terhadap kinerja pegawai pada PD BPR BKK Kebumen. Hal ini terlihat dari niai determinasi $R$ Adjusted Square $=0,419$ hal ini berarti, model persamaan regresi tersebut hanya mampu menjelaskan variasi naik turunnya vaiabel kinerja pegawai pada PD BPR BKK Kebumen sebesar $\quad 41,9 \%$ sedangkan sisanya sebesar 58,1\% lagi dipengaruhi oleh variabel lain yang tidak dimasukkan dalam persamaan regresi.

\section{Uji t}

Uji $\mathrm{t}$ dipakai untuk melihat signifikansi dari pengaruh independen secara individu terhadap variabel dependen dengan menganggap variabel lain konstan. Uji ini bisa dilakukan dengan membandingkan toleransi error 0,05 .

Variabel X1 (kualitas kehidupan kerja) memiliki $\mathrm{t}$ hitung sebesar 1,170 sedangkan nilai signifikansi sebesar 0,246. Karena nilai signifikansi lebih dari 0,05 , hal ini menunjukkan bahwa variabel kualitas kehidupan kerja (X1) memiliki hubungan yang tidak signifikan/tidak berarti terhadap kinerja pegawai PD BPR BKK Kebumen.
Variabel X2 (kompetensi) memiliki $t$ hitung sebesar 2,250 sedangkan nilai signifikansi sebesar 0,028 . Karena nilai signifikansi kurang dari 0,05 , hal ini menunjukkan bahwa variabel kompetensi (X2) memiliki hubungan yang signifikan/berarti terhadap kinerja pegawai PD BPR BKK Kebumen.

Variabel X3 (disiplin kerja) memiliki $t$ hitung sebesar 2,027 sedangkan nilai signifikansi sebesar 0,047. Karena nilai signifikansi kurang dari 0,05, hal ini menunjukkan bahwa variabel disiplin kerja (X3) memiliki hubungan yang signifikan/berarti terhadap kinerja pegawai PD BPR BKK Kebumen.

\section{Uji F}

Uji $F$ adalah uji yang dipakai untuk melihat apakah variabel independen secara bersama-sama berpengaruh secara signifikan terhadap variabel dependen. Uji $F$ juga untuk mengetahui apakah model regresi dapat digunakan untuk memprediksi variabel dependen atau tidak. Signifikansi berarti hubungan yang terjadi dapat berlaku untuk populasi (dapat digeneralisasikan). Uji ini bisa dilakukan dengan membandingkan nilai signifikansi $\mathrm{F}$ dengan toleransi error 0,05 .

Berdasarkan hasil analisis melalui regresi berganda ditemukan bahwa nilai $\mathrm{F}$ hitung model regresi ini adalah 18,077 dengan nilai signifikansi 0,000, hal ini berarti variabel independen yang terdiri dari kualitas kehidupan kerja, kompetensi dan disiplin kerja secara bersama-sama memiliki hubungan seecara signifikan terhadap variabel dependen yang merupakan kinerja pegawai PD BPR BKK Kebumen. 


\section{Pembahasan}

Berdasarkan analisis data penelitian yang telah diuraikan di atas, maka dapat disampaikan pembahasan hasil penelitian sebagai berikut:

1. Apabila koefisien regresi tetntang kualitas kehidupan kerja meningkat dengan menganggap bahwa variabel lain tetap, maka kinerja pegawai PD BPR BKK Kebumen akan meningkat. Hasil berdasarkan uji t untuk mencari hubungan individual menujukkan bahwa kualitas kehidupan kerja secara parsial memberikan hubungan yang signifikan terhadap kinerja pegawai PD BPR BKK Kebumen.

2. Apabila koefisien regresi kompetensi meningkat dengan mengganggap bahwa variabel lain tetap, maka kinerja pegawai PD BPR BKK Kebumen akan meningkat. Hasil berdasarkan uji $\mathrm{t}$ untuk mencari hubungan individual menujukkan bahwa kompetensi secara parsial memberikan hubungan yang signifikan terhadap kinerja pegawai PD BPR BKK Kebumen.

3. Apabila koefisien regresi disiplin kerja meningkat dengan mengganggap bahwa variabel lain tetap, maka kinerja pegawai PD BPR BKK Kebumen akan meningkat. Hasil berdasarkan uji $\mathrm{t}$ untuk mencari hubungan individual menujukkan bahwa kompetensi secara parsial memberikan hubungan yang signifikan terhadap kinerja pegawai PD BPR BKK Kebumen.

Sesuai dengan paparan di atas, temuan penelitian ini menunjukkan bahwa kinerja pegawai pada PD BPR BKK Kebumen berhubungan dengan kualitas kehidupan kerja, kompetensi dan disiplin kerja.

\section{Implikasi Manajerial}

Berdasarkan hasil analisis korelasi yang telah dibahas dan disimpulkan bahwa pengaruh antara kualitas kehidupan kerja (X1), kompetensi (X2) dan disiplin kerja (X3) dengan kinerja pegawai pada PD BPR BKK Kebumen dapat ditarik implikasi penelitian dalam rangka meningkatkan kinerja dapat dilakukan dengan meningkatkan kualitas kehidupan kerja organisasi, meningkatkan kompetensi pegawai dan disertai adanya peningkatan disiplin kerja pegawai.

Dari hasil penelitian mengindikasikan bahwa: Pertama, kualitas kehidupan kerja merupakan program yang mencakup cara untuk meningkatkan kualitas kehidupan kerja pegawai dengan menciptakan pekerjaan yang lebih baik. Oleh karena itu dimensi-dimensi kualitas kehidupan kerja seperti; partisipasi karyawan, penyelesaian konflik, komunikasi, kesehatan kerja, keselamatan kerja, keamanan kerja, kompensasi yang layak, kebanggaan dan pengembangan karir dipandang mampu untuk meningkatkan kinerja yang baik dari para pegawai terhadap organisasi.

Dengan demikian organisasi yang menciptakan kualitas kehidupan kerja diharapkan para pegawai akan lebih dilibatkan dalam perencanaan dalam bekerja, karyawan juga lebih terjamin keamanan dalam bekerja dan karir pegawai juga akan lebih baik. Hal ini akan membatu para pegawainya untuk lebih produktif dalam bekerja sehingga kinerja pegawai tersebut dapat meningkat.

Kedua, kompetensi merupakan karakteristik dasar dari seseorang yang memungkinkan mereka menghasilkan kinerja terbaik dalam pekerjaannya, 
sesuai dengan dimensi-dimensi dalam kompetensi seperti: motives, traits, self concept, knowledge dan skill dipandang mampu untuk meningkatkan kinerja yang baik dari para pegawai.

Pegawai yang memiliki kompetensi yang baik maka mampu untuk membedakan antara pegawai yang sukses dalam bekerja. Pegawai yang memiliki kompetensi yang baik dapat memiliki motivasi yang kuat, memiliki sikap yang profesional dalam bekerja dan memiliki ketrampilan yang baik. Untuk itu perlu sekiranya organisasi untuk mengadakan pelatihan-pelatihan untuk dapat meningkatkan kompetensi dari para pegawai.

Ketiga; disiplin kerja merupakan suatu sikap, tingkah laku, dan perbuatan yang sesuai dengan peraturan baik tertulis maupun tidak tertulis, dan bila melanggar akan ada sanksi atas pelanggarannya, sesuai dengan dimensi-dimensi sebagai berikut; disiplin terhadap tugas, disiplin terhadap waktu, disiplin terhadap aturan-aturan, senang dalam bekerja dan adanya sanki. Oleh karena itu dimensi-dimensi dalam disiplin kerja tersebut dipandang mampu untuk meningkatkan kinerja yang baik dari para pegawai di dalam organisasi.

Jika organisasi konsisten dalam menerapkan aturan-aturan yang membentuk perilaku disiplin kerja pegawai maka hal ini bisa menjadi peluang yang perlu digali untuk mewujudkan kinerja pegawai yang lebih baik dengan meningkatkan tangggungjawab terhadap tugas, disiplin terhadap pekerjaan dan kesediaan dalam menerima sangsi jika pegawai melanggar aturan.

Dengan demikian, diharapkan untuk dapat meningkatkan kinerja pegawai pada PD BPR BKK Kebumen adalah sebagai berikut; 1) Dari pihak organisasi/manajemen diharapkan untuk betul-betul memperhatikan masalah-masalah yang berkaitan dengan kualitas kehidupan kerja pegawai karena ketika organisasi menciptakan kualitas kehidupan kerja yang baik akan dapat meningkatkan kinerjanya. 2) Untuk para pegawai pada PD BPR BKK Kebumen diharapkan untuk terus meningkatkan kompetensi yang dimiliki, baik melalui pelatihan yang diprogramkan oleh organisasi maupun melalui pendidikan lanjut karena dengan kompetensi yang dimiliki pegawai baik akan mampu meningkatkan kinerjanya. 3) Organisasi harus dengan tegas dan konsisten dalam menerapkan aturanaturan yang berlaku bagi semua pegawai karena dengan kosistensi penegakan aturan dapat membimbing para pegawai untuk terus berperilaku disiplin.

\section{Keterbatasan Penelitian}

Adapun keterbatasan dalam penelitian ini adalah:

1. Penelitian ini hanya terbatas pada variabel kualitas kehidupan kerja, kompetensi, disiplin kerja dan kinerja pegawai, sedangkan masih banyak faktor lain yang dapat mempengaruhi kinerja pegawai.

2. Penelitian ini hanya menggunakan 72 sampel pegawai dari 251 populasi yang terdapat di PD BPR BKK Kebumen

3. Variabel yang mungkin berhubungan dengan kinerja pegawai PD BPR BKK Kebumen tidak hanya terbatas pada dua variabel di atas, tetapi masih banyak variabel-variabel lain yang mungkin berhubungan dengan usaha meningkatkan kinerja pegawai dengan memperluas variabel-variabel atau sub variabel yang terlibat dalam penelitian; 
misalnya kompensasi, pelatihan, motivasi, pengembangan karir dan lain-lain.

\section{Saran Untuk Peneliti Selanjutnya}

Berdasarkan penemuan empiris yang telah diperoleh melalui penelitian ini, maka pada bagian akhir penulisan ini, peneliti menyampaikan beberapa saran untuk penelitian selanjutnya adalah sebagai berikut;

1. Lingkup penelitian diperluas terhadap semua unit dengan memperbanyak responden, agar hasil penelitian menjadi masukan yang lebih lengkap sebagai bahan pertimbangan organisasi dalam menentukan kebijakan pembinaan dan pengembangan pegawai.

2. Diperlukan bantuan materil dan moral dari pihak pimpinan, agar para pegawai memberikan perhatian dan kepedulian terhadap pelaksanaan penelitian, sehingga proses penelitian tersebut dapat lancar, tepat waktu, serta memperoleh data yang akurat.

3. Bagi peneliti yang tertarik untuk menjadikan penelitian ini menjadi penelitian referensi sehingga hasilnya dapat dibandingkan dari waktu ke waktu.

\section{DAFTAR PUSTAKA}

Arikunto, Suharsimi, (2005). Manajemen Penelitian. Cetakan ketujuh, Penerbit Rineka Cipta, Jakarta

A Dale Timpe 2002, Memimpin Manusia, Seri Ilmu dan Seni Manajemen Bisnis. PT Gramedia Asri Media, Jakarta

Algifari, (2000), Analisa Regresi. Edisi 2. Yogyakarta: BPFE Yogyakarta

Cascio, Wayne F. (2006) Managing Human Resources: Productivity, Quality of Work Life, Profit.Singapore: McGraw-Hill International Edition.

Flippo, E. B. (2005). Manajemen Personalia Jilid 1 (Edisi keenam). Erlangga, Jakarta

Ghozali, Imam. (2006). Analisis Multivariate Lanjutan dengan Program SPSS. Semarang, Indonesia: Badan Penerbit Universitas Diponegoro

Gomes, Faustino Cardoso, (2003), Manajemen Sumber Daya Manusia, Penerbit Andi, Yogyakarta.

Kartikawangi, (2002), Karakteristik Sumber Daya Manusia Yang Dibituhkan Dunia Industri/Organisasi Dalam Menghadapi Globaalisasi, Atmajaya Nan Jaya, Jakarta

Mangkunegara, (2007). Manajemen Sumber Daya Manusia Perusahaan, Rosda.

Mangkuprawira. (2007). Manajemen Mutu Sumber Daya Manusia, Galia, Bogor, Indonesia.

Mathis, Jackson, 2002, Manajemen Sumber Daya Manusia, Edisi pertama, Cetakan Pertama, Yogyakarta : Salemba Empat

Rivai, Veithzal (2004). Manajemen Sumber Daya Manusia untuk Perusahaan, Raja Grafindo Persada, Jakarta

Robbins, Stephen, (2006), Perilaku Orgaisasi: Edisi Lengkap, Indeks

Siagian, S. P. (2007). Manajemen Sumber Daya Manusia. Bumi Aksara, Jakarta

Santoso, (2000). SPSS Statistik Parametrik, PT. Elex Media Komputindo Kelompok Gramedia, Jakarta.

Santoso, (2004). Ergonomi Manusia, Peralatan, dan Lingkungan. Sidoarjo. Prestasi pustaka publisher 
Sedarmayanti. (2007). Manajemen SDM Cetakan 1. PT. Refika Aditama. Bandung

Sugiono, (2008). Metode Penelitian Pendidikan. Bandung, Alfabeta

Suhendi, Hendi, (2010), Perilaku Organisasi, CV Pustaka Setia, Bandung

Umar, H., (2000). Metode Penelitian Untuk Skrpsi dan Tesis Bisnis, Cetakan Ketiga. PT. Raja Grafindo Persada, Jakarta

Wibowo, (2007) Manajemen Kinerja, Rajawali Pers

Wirawan (2009). Evaluasi Kinerja Sumber Daya Manusia : Teori, Aplikasi dan Penelitian, Salemba Empat, Jakarta.

Husnawati, (2006). Analisis Pengaruh Kualitas Kehidupan Kerja Terhadap Kinerja Karyawan Dengankomitmen Dan Kepuasan Kerja Sebagai Intervening Variabel (Studi Pada Perum Pegadaian Kanwil VI Semarang), Tesis. Pascasarjana Universitas Diponegoro, Semarang.

Ayuningrum, (2010). Pengaruh Kompetensi Sumber Daya Manusia Terhadap Kinerja Karyawan di PT.PP. London Sumatra Tbk Medan, Universitas Sumatera Utara.

Joko, Sarwanto, (2008). Pengaruh Disiplin Kerja Terhadap Kinerja Karyawan Di. Kantor Departemen Agama Kabupaten Karanganyar. UIN Sunan Kalijaga. 